\title{
Characterization of recombinant Bacillus halodurans CM1 xylanase produced by Pichia pastoris KM71 and its potential application in bleaching process of bagasse pulp
}

\author{
Haniyya $^{1}$, Lina Mulyawati ${ }^{1}$, Is Helianti ${ }^{1,}{ }^{*}$, Phitsanu Pinmanee ${ }^{2}$, Kanokarn Kocharin $^{3}$, Duriya Cantasingh ${ }^{2}$, Thidarat Nimchua ${ }^{2}$ \\ ${ }^{1}$ Center for Bioindustrial Technology, Agency of Assessment and Application of Technology (BPPT), Building 611/614, LAPTIAB-BPPT, \\ PUSPIPTEK Area, Setu, South Tangerang 15314, Indonesia \\ 2Enzyme Technology Research Team, Biorefinery and Bioproduct Technology Research Group, National Center for Genetic Engineering and \\ Biotechnology,113 Phahonyothin Road, Khlong Nueng, Khlong Luang, Pathum Thani 12120, Thailand \\ ${ }^{3}$ Microbial Cell Factory Research Team, Biorefinery and Bioproduct Technology Research Group, National Center for Genetic Engineering \\ and Biotechnology, 113 Phahonyothin Road, Khlong Nueng, Khlong Luang, Pathum Thani 12120, Thailand \\ ${ }^{*}$ Corresponding author: is.helianti@bppt.go.id
}

SUBMITTED 9 July 2020 REVISED 19 October 2020 ACCEPTED 10 December 2020

\begin{abstract}
Thermoalkalophilic xylanases promise potential application in pulp biobleaching to reduce the use of toxic chlorinated chemical agents, which are harmful to the environment. In this study, a thermoalkalophilic endoxylanase gene (bhxyn3) originating from Indonesian indigenous Bacillus halodurans CM1 was cloned into yeast expression vector pPICZa A and expressed in Pichia pastoris KM71 under the control of AOX1 promoter. Recombinant P. pastoris expressed the highest final level of xylanase $(146 \mathrm{U} / \mathrm{mL})$ on BMGY medium after five days of cultivation. Optimization of xylanase production on a small scale was carried out by varying the methanol concentrations and the optimal xylanase production by the recombinant P. pastoris was observed in the culture with $2 \%(\mathrm{v} / \mathrm{v})$ methanol after four days of the induction phase. The recombinant xylanase (BHxyn3E) was thermotolerant and alkalophilic, with an optimal temperature at around $55-65^{\circ} \mathrm{C}$ and under $\mathrm{pH}$ 8.0. The enzyme activity was slightly induced by $\mathrm{K}^{+}, \mathrm{Fe}^{2+}$, and $\mathrm{MoO}_{4}{ }^{2-}$. Enzymatic bleaching of bagasse pulp with no prior $\mathrm{pH}$ adjustment ( $\mathrm{pH}$ 9) using BHxyn3E at $200 \mathrm{U} / \mathrm{g}$ oven dried pulp increased the lightness index $\left(\mathrm{L}^{*}\right)$ and changed substantially the color a index $\left(a^{*}\right)$; however, the treatments did not change the whiteness index in a significant way. Therefore, further optimization and assessment such as adjustment of incubation temperature and $\mathrm{pH}$ in biobleaching were needed to reduce the use of harmful chemical agents in industrial applications.
\end{abstract}

KEYWORDS Bacillus halodurans; biobleaching; cellulase-free xylanase; Pichia pastoris; thermoalkalophilic xylanase

\section{Introduction}

Remarkable interest has been focused on integrating hydrolytic enzymes, such as xylanases, that degrade xylan components in plant cell walls into non-complex sugars in industries, particularly in the pulp and paper industry. Xylanases (EC 3.2.1.8) are produced by microorganisms and considered as the key enzymes that hydrolyze $\beta-1,4-$ xylans to lead to the degradation of complex polysaccharides (Jeya et al. 2009). On the other hand, the enzymes have widespread potential applications to be used in such a wide range of industrial fields (textile, feed, beverage, and biofuels) since its ability to facilitate the removal of xylan through partial hydrolysis of lignin carbohydrate complexes, thereby enabling lignin removal from raw materials allowing it to be processed in the next stages of manufacturing. In the pulp and paper process, this fragmentation of xylan polymer allows residual lignin attached to the remaining xylan complex, to be exposed by the efficient used bleaching agents. Thus, pretreatment of pulp using xylanases can reduce the load of chlorine and chlorinebased compounds in the subsequent chemical bleaching stages. As a side effect, the utilization of cellulase-free xylanase enable to enhance several physical pulp properties, such as brightness, tensile strength, and tear factor without affecting the cellulose fiber strength of paper products (Zhao et al. 2015).

Currently, xylanases that are intended to be used in the industrial bleaching process must be robust to operate in extreme conditions since most operations were conducted under high temperature and strong alkaline $\mathrm{pH}$ for at least an-hour long. Hence it must be adaptable in such an extreme environment. Xylanases are produced by members of bacteria and fungi, commonly in group of bacterial xylanases display an active at mesophilic temperatures (below $50{ }^{\circ} \mathrm{C}$ ) in acidic or neutral $\mathrm{pH}$ (Walia et al. 2017). 
Although several xylanases with thermo and alkali stability were isolated, there is still high demand for thermoalkalophilic xylanases for application in paper processing (Bhardwaj et al. 2019).

In the previous study, thermoalkalophilic Bacillus halodurans CM1 from Cimanggu Hot Spring located in West Java area in Indonesia has been isolated. Xylanase produced by this bacterial strain was active in alkaline condition with the optimum activity at $70{ }^{\circ} \mathrm{C}$ and at $\mathrm{pH} 9$ (Ulfah et al. 2011). Cloning of an endo-xylanase encoding gene (1191 bp) from this strain using pET21d vector in Escherichia coli BL21 star have been previously conducted, and the obtained recombinant protein of BHxyn3E (46.7 kDa) showed a potential to promote xylan reduction in deinking process of waste paper (Helianti et al. 2018). However, the level of the secreted enzyme from recombinant $E$. coli was expressed very low. To increase enzyme productivity, changing the recombinant expression system is necessary. In this study, the gene encoded target xylanase was thus expressed into Pichia pastoris expression system. The yeast $P$. pastoris can neither utilize nor degrade xylan, but it is able to boost a higher expression level of heterologous gene extracellularly (Mohd Dali et al. 2011) with a high purity level of target protein after culturing in less expensive culture media without the presence of antibiotics for upscaled mass production (Shang et al. 2017). The cloned gene is also directly integrated into its chromosomal DNA through common genetic manipulation, thereby reducing the cost for plasmid maintenance (Chantasingh et al. 2006). Hence, all mentioned features have made $P$. pastoris very useful for a protein expression system.

Considering these facts, our present research studies aim to clone the thermoalkalophilic xylanase gene originating from $B$. halodurans CM1 in an expression vector with a strong promoter, pPICZ $\alpha$ A, and express it in $P$. pastoris KM71 to evaluate its performance in the pulp bleaching process. The enzyme production and biochemical characterization of the obtained xylanase were investigated. Thus, crude xylanase was employed to evaluate its effectiveness in the biobleaching of bagasse pulp, which is one of the most available papermaking lignocellulosic fiber resources in many developing countries, including Thailand and Indonesia (Sudaryanto et al. 2008; Hidayat and Yasuyuki 2012).

\section{Materials and Methods}

\subsection{Culture preparation}

E. coli DH5 $\alpha$ (Invitrogen, Waltham, Massachusetts, USA) was used for cloning host and plasmid propagation. Following the transformation, E. coli DH5 $\alpha$ transformants were selected at $37^{\circ} \mathrm{C}$ on the low-salt Luria Bertani (LB) agar medium supplemented with $25 \mu \mathrm{g} / \mathrm{mL}$ zeocin. P. pastoris KM71 strain (Invitrogen, Waltham, Massachusetts, USA) was used as the host for xylanase expression using YPD containing $10 \mathrm{~g} / \mathrm{L}$ yeast extract, $20 \mathrm{~g} / \mathrm{L}$ peptone, and $20 \mathrm{~g} / \mathrm{L}$ glucose to grow. The same media but with an additional $100 \mu \mathrm{g} / \mathrm{mL}$ zeocin was used for P. pastoris transformants selection. Recombinant plasmid pET21d harboring the target xylanase gene originating from $B$. halodurans CM1 (bhxyn3) with the accession number of KU759320 (Helianti et al. 2018) has been used for the insert, while pPICZ $\alpha$ A for expression vector (Invitrogen, Waltham, Massachusetts, USA). All primers used in the study were synthesized and supplied by Integrated DNA Technologies, Inc. (IDT, Singapore).

\subsection{Construction of the recombinant plasmid (pPICZaA-bhxyn3) and gene integration for secreted xylanase expression}

An E. coli/ P. pastoris shuttle vector, pPICZ $\alpha$ A, was used to express the target xylanase (BHxyn3E) extracellularly. The bhxyn3 gene is a 1191 bp DNA fragment encoding the mature BHxyn3E peptide (397 aa) (Helianti et al. 2018). The bhxyn3 gene was amplified using the following genespecific primers that included the forward primer (Xyn-F; 5'-GCATGAATTCGCTCAAGGGGACCAAAATCC3') and the reverse primer (Xyn-R; 5'CATATCTAGAGCATCGATAATTCTCGAGTAAGCA GGTTTC-3') with its respective EcoRI and an $\mathrm{XbaI}$ restriction sites (underlined). The PCR program was started by initial denaturation at $98{ }^{\circ} \mathrm{C}$ for $30 \mathrm{~s}$, followed by 35 cycles of $98^{\circ} \mathrm{C}$ for $10 \mathrm{~s}$, annealing at $55^{\circ} \mathrm{C}$ for 30 $\mathrm{s}$ and $72{ }^{\circ} \mathrm{C}$ for $90 \mathrm{~s}$ and ended by the final extension at $72{ }^{\circ} \mathrm{C}$ for $10 \mathrm{~min}$. Afterward, the bhxyn 3 gene obtained from PCR amplification was digested with EcoRI and XbaI (Thermoscientific, Waltham, Massachusetts, USA) and cloned into pPICZ $\alpha$ A vector located right after $A O X$ promoter through restriction cloning. The selected recombinant plasmid, pPICZ $\alpha \mathrm{A}-b h x y n 3$ was confirmed by restriction analysis and sequencing.

After the sequence of bhxyn3 ORF was verified, the obtained recombinant plasmid pPICZ $\alpha$ A-bhxyn3 was linearized with PmeI for P. pastoris integration. Linearized DNA was then transformed into P. pastoris KM71 by electroporation, thus allowed the integration of cloned gene into its genomic DNA. The homolog sequence of AOX1 promoter in the plasmid and the genomic DNA of $P$. pastoris initiates the integration of the whole gene cassette through homologous recombination. Positive recombinants were selected and monitored by colony PCR using 5'AOX1 and 3'AOX1 primers.

\subsection{Expression of recombinant xylanase in P. pastoris}

An overnight culture was prepared by cultivating a single colony of transformant into $5 \mathrm{~mL}$ of YPD at $30^{\circ} \mathrm{C}$ with shaking at $250 \mathrm{rpm}$. Seed culture was then added into 5 $\mathrm{mL}$ of fresh buffered minimal glycerol complex medium (BMGY; 1\% yeast extract, 2\% peptone, $0.1 \mathrm{M}$ potassium phosphate buffer $\mathrm{pH} 6.0,1.34 \%$ yeast nitrogen base, 0.4 $\mu \mathrm{g} / \mathrm{mL}$ biotin, and $1 \%$ glycerol) containing zeocin (100 $\mu \mathrm{g} / \mathrm{mL}$ ) at $30{ }^{\circ} \mathrm{C}$ with constant shaking (250 rpm) until cell density of 5-6 OD $_{600}$ was reached (Chantasingh et al. 2006). After that, the cell pellet was collected by centrifu- 
gation at $5000 \times \mathrm{g}$ for $10 \mathrm{~min}$ and resuspended in about $1 / 5$ volume of the initial culture of buffered minimal methanol medium (BMMY; 1\% yeast extract, 2\% peptone, $0.1 \mathrm{M}$ potassium phosphate buffer $\mathrm{pH}$ 6.0, 1.34\% yeast nitrogen base, $0.4 \mu \mathrm{g} / \mathrm{mL}$ biotin, and $2 \%$ methanol). The target gene was regulated under $A O X 1$ promoter, which required methanol as an inducer. Since methanol is very easy to evaporate, in order to maintain its concentration during the induction phase, $100 \%$ methanol was regularly added into the culture every $24 \mathrm{~h}$ to a final concentration of $3 \%(\mathrm{v} / \mathrm{v})$ (Chantasingh et al. 2006). The crude extract from culture supernatant from day 1 to 6 was subjected for activity assay and SDS-PAGE analysis (Chantasingh et al. 2006).

\subsubsection{Effect of zeocin on expression level of recombi- nant xylanase}

To investigate the effect of zeocin on xylanase expression, positive recombinant (P. pastoris KM71/pPICZ $\alpha \mathrm{A}-$ bhxyn3) was grown in YPD medium overnight before about $0.5 \%(\mathrm{v} / \mathrm{v})$ seed cultures were inoculated into $100 \mathrm{~mL}$ BMGY medium incorporated with zeocin (100 $\mu \mathrm{g} / \mathrm{mL}$ ) in a 1-L flask and grown at $30{ }^{\circ} \mathrm{C}$ overnight with shaking condition (250 rpm) or until the cell density reached 0.5-0.8 $\mathrm{OD}_{600}$ culture. Afterward, the media was changed by the resuspension of harvested cells with $20 \mathrm{~mL}$ of BMMY medium to start the induction phase with the daily supplementation of methanol to the same final concentration of $2 \%(\mathrm{v} / \mathrm{v})$ for four days. The culture broth was collected on days 3 and 4 to determine the xylanase activity. An additional experimental sample was also conducted using BMGY medium devoid of zeocin.

\subsubsection{Effect of methanol concentrations on the ex- pression level of recombinant xylanase}

The culture of the $P$. pastoris in BMMY medium was performed in the same manner as described above, except the final concentrations of methanol were varied from 1 to $4 \%$ $(\mathrm{v} / \mathrm{v})$ throughout the induction phase.

Xylanase assay was performed by determining the reducing sugar liberated from beechwood xylan (SigmaAldrich, Munich, Germany) according to the method described by Bailey et al. (1992) with triplicates. The reaction mixture was composed of $20 \mu \mathrm{L}$ of recombinant xylanase and $320 \mu \mathrm{L}$ of $50 \mathrm{mM}$ Tris-HCl buffer (pH 8.0) containing $1.0 \%(\mathrm{w} / \mathrm{v})$ beechwood xylan. After $5 \mathrm{~min}$ incubation at $60^{\circ} \mathrm{C}$, the reaction was cooled on ice to stop the reaction. The amount of reducing sugars liberated in the mixture was determined by detecting 3, 5-dinitrosalicylic acid (DNS) reagent as xylose equivalents at $540 \mathrm{~nm}$. One unit (U) of xylanase activity was defined as the amount of enzyme that releases reducing sugar at the rate of $1 \mu \mathrm{mol}$ per minute under the assay conditions.

\subsection{Enzyme Characterization}

\subsubsection{Effect of $\mathrm{pH}$ and temperature on enzyme activ- ity and stability}

The effect of $\mathrm{pH}$ and temperature on xylanase activity was investigated as described by Nimchua et al. (2012). Briefly, the optimal $\mathrm{pH}$ was determined by executing the enzyme activity assay in the $\mathrm{pH}$ range of 5.0 to 10.0 . The buffers used were $50 \mathrm{mM}$ sodium citrate (pH 5.0), $50 \mathrm{mM}$ sodium phosphate (pH 6.0 to 8.0$), 50 \mathrm{mM}$ Tris- $\mathrm{HCl}(\mathrm{pH}$ 8.0 to 9.0 ) and $50 \mathrm{mM}$ Glycine- $\mathrm{NaOH}$ (pH 9.0 to 10.0), respectively. Assays at different temperatures were performed at the optimal $\mathrm{pH}$ over a temperature range of 30 to $80{ }^{\circ} \mathrm{C}$. The $\mathrm{pH}$ stability of xylanase was measured by preincubating the enzyme in various pHs ranged from 6 to 10 for one $\mathrm{h}$, followed by activity determinations. Thermal stability was monitored by heating the enzyme for different times (15, 30, 45 and $60 \mathrm{~min})$ at various temperatures (50, 60 and $70^{\circ} \mathrm{C}$ ). In the stability assays, the enzyme samples were determined for remained activity instantly after incubation.

\subsubsection{Effect of ions and additives on xylanase activity}

To study the effect of ions and additives on xylanase activity, various ions, detergents, polymers and other additives were supplemented into the enzyme mixtures with final concentrations of $1 \mathrm{mM}\left(\mathrm{CoCl}_{2}\right.$, $\mathrm{ZnCl}_{2}, \mathrm{KI}, \mathrm{Na}_{2} \mathrm{MoO}_{4} \cdot 2 \mathrm{H}_{2} \mathrm{O}, \mathrm{CuSO}_{4} \cdot 5 \mathrm{H}_{2} \mathrm{O}, \mathrm{FeSO}_{4} \cdot 7 \mathrm{H}_{2} \mathrm{O}$, $\mathrm{FeSO}_{4} .7 \mathrm{H}_{2} \mathrm{O}$ and $\left.\mathrm{MnSO}_{4} .2 \mathrm{H}_{2} \mathrm{O}\right)$ and $5 \mathrm{mM}\left(\mathrm{K}_{2} \mathrm{SO}_{4}\right.$, $\mathrm{CaCl}_{2}, \mathrm{MgSO}_{4} \cdot 7 \mathrm{H}_{2} \mathrm{O}$ and $\left.\left(\mathrm{NH}_{4}\right)_{2} \mathrm{SO}_{4}\right)$ for ions, $0.25 \%$ $(\mathrm{w} / \mathrm{v})$ for detergents (Triton X-100, Tween 20, Tween 80, Lutensol and Sanmorin), $0.02 \%(\mathrm{w} / \mathrm{v})$ for polymers (PEG4000 and PEG8000), 15\% (w/v) for trehalose and $50 \%$ (v/v) for glycerol in $50 \mathrm{mM}$ Tris-HCl buffer ( $\mathrm{pH} 8.0$ ). The residual xylanase activities in reaction mixtures containing ions and other additives were determined at $60{ }^{\circ} \mathrm{C}$ for 60 and $180 \mathrm{~min}$. The enzyme reaction without additive was used as the control.

\subsection{Application of recombinant xylanase from $B$. halo- durans CM1 in bagasse pulp bleaching}

\subsubsection{Optimization of enzyme dosage and additive formulation for biobleaching}

In this study, optimization of related reaction parameters for biobleaching was investigated as followed and using unbleached bagasse pulp from the Thai local pulp and paper company. Enzyme dose was optimized for pulp bleaching by treating the unbleached bagasse pulp with various enzyme concentrations, ranging from 0 to $200 \mathrm{U} / \mathrm{g}$ oven dried (OD) pulp. All the experiments were carried out using $10 \mathrm{~g}$ OD pulp in a plastic bag at $10 \%$ pulp consistency under the temperature of $60{ }^{\circ} \mathrm{C}$ for one $\mathrm{h}$ with no $\mathrm{pH}$ adjustment (the $\mathrm{pH}$ of pulp solutions was 9.0 after preparing the bleaching reactions). Pulp consistency is measured by the percentage by weight of dry substances (in this study bone-dry (\%)). According to TAPPI T240, the value of pulp consistency used is essential as it defines 
control of the percentage of dry fibers in $100 \mathrm{~g}$ of pulpwater mixture.

Effect of non-ionic surfactants and wetting agent towards enzyme efficiency in pulp bleaching was studied by carrying out the enzymatic treatment of the unbleached pulp (0.075 g OD pulp) in 50-mL test tube at 7.5\% pulp consistency without $\mathrm{pH}$ adjustment. The treated enzyme solutions at optimal dosage were mixed with different surfactants (Tween 20, Tween 80, Triton X-100, or Lutensol) and wetting agent (Sanmorin, Sanyo Kasei, Thailand) at the concentration of $0.25 \%(\mathrm{w} / \mathrm{v})$ and immediately used the pulp at $60^{\circ} \mathrm{C}$ for $1 \mathrm{~h}$ under shaking (200 rpm). The effect of additive concentrations towards xylanase activity in bleaching of bagasse pulp was investigated using a selected surfactant obtained from the screening experiment. The enzymatic treatment of the pulp was performed in the same manner as mentioned above, except doses of the selected additive ranging from 0 to $2 \%(\mathrm{w} / \mathrm{v})$.

The bleaching solutions were collected after enzyme treatments by filtering through Supor ${ }^{\circledR}$ PES Membrane (Pall Corporation, Bangkok, Thailand) to remove the pulp debris and any particulates. The amount of reducing sugar appeared in the filtrates was quantified using DNS assay by Miller (1959), with xylose used as a standard. In addition, all filtrated samples and reagent solutions were re-filtered through $0.2 \mu \mathrm{m}$ sterile membrane and then degassed prior to HPLC characterization of the specific solubilized sugars such as xylose and glucose. Analysis of monomeric sugars was performed using HLPCDIONEX ${ }^{\circledR}$ UltiMate 3000 RS (Thermoscientific, Waltham, Massachusetts, USA) and the conditions were: Column: Aminex ${ }^{\circledR} H P X-87$ H column $(300$ x 7.8 $\mathrm{mm}$; Bio-Rad), mobile phase: $5 \mathrm{mM}$ sulphuric acid, flow rate: $0.5 \mathrm{~mL} / \mathrm{h}$, column temperature: $65 \pm 1{ }^{\circ} \mathrm{C}$, Detector: Refractive Index (RI), injection volume: $20 \mu \mathrm{L}$ and run time: $30 \mathrm{~min}$. Control was prepared identically to the enzymatic treatment with enzyme replaced by distilled water.

\subsubsection{Pulp bleaching with enzyme treatment}

Bleaching of the bagasse pulp was executed in $50 \mathrm{~g}$ batches in transparent plastic bags using 3-step sequence (X)HEP: xylanase pretreatment (X-stage), followed by sodium hypochlorite bleaching ( $\mathrm{H}$-stage), and alkaline extraction with sodium hydroxide in the presence of hydrogen peroxide (EP-stage), respectively. The conditions for each bleaching step are indicated as followed.

In the X-stage condition, $10 \%$ pulp consistency at 60 ${ }^{\circ} \mathrm{C}$ and $\mathrm{pH} 8.0$ for one $\mathrm{h}$; the pulp was pretreated with $\mathrm{xy}-$ lanase (100 U/g OD pulp) and a mixture of xylanase (100 U/g OD pulp and Triton X-100 (0.25\% (w/v)), while control pulp was bleached identically without adding the enzyme. In the H-stage, the pulp was treated with $8 \%(\mathrm{w} / \mathrm{w})$ sodium hypochlorite at $50^{\circ} \mathrm{C}$ and $\mathrm{pH} 3.0-4.0$ for $2 \mathrm{~h}$. This stage was followed by the final EP-stage where treatment with $0.25 \%(\mathrm{w} / \mathrm{w}) \mathrm{NaOH}$ and $5 \%(\mathrm{w} / \mathrm{w}) \mathrm{H}_{2} \mathrm{O}_{2}$ was performed at $70{ }^{\circ} \mathrm{C}$ and $\mathrm{pH} 10-11$ for one $\mathrm{h}$.
In each step, the plastic bags containing pulp were immersed in a water bath at designated temperatures and then washed several times with tap water prior to use in the next stage. Controls included unbleached pulp, pulp treated with distilled water and pulp treated with xylanase at Xstage were prepared in the same manner. After bleaching sequence, the resulted pulp was homogenized for making hand sheets according to TAPPI T218. The paper color and lightness of each hand sheet were determined with a spectrocolorimeter (Data Color Spectrum 650 TM, Lawrenceville, New Jersey, USA) using CIE L*a*b* notation referring to the method of TAPPI T560.

\section{Results and Discussion}

\subsection{Construction of expression vector and expression of B. halodurans CM1 xylanase gene}

In this study we obtained our target gene by executing PCR on pET21d vector containing the bhxyn3 gene as a DNA template using designed Xyn-F and Xyn-R primers. A DNA fragment of 1191 bp was obtained and cloned in frame with $\alpha$-factor secretion signal in the yeast expression vector, pPICZ $\alpha \mathrm{A}$, under the control of AOX1 promoter. The obtained recombinant DNA was well confirmed with $100 \%$ sequence similarity to the $B$. halodurans CM1 xylanase, and then the DNA was transformed into P. pastoris KM71. The transformants were screened by colony PCR technique using 5' AOX1 and 3' AOX1 primers to validate whether gene recombination has successfully occurred in the host genome. The $A O X 1$ promoters region in the plasmid are homologous with $A O X 1$ promoters in the genome of $P$. pastoris, thereby promoting the integration of our target gene and its expression became tightly regulated by this promoter.

Among four recombinant clones tested, high level of xylanase induction was observed from an integrant, so called pPICZ $\alpha$ A-bhxyn3 after 3-6 d of induction (Figure

TABLE 1 Effect of different cations and salts on the recombinant xylanase activity.

\begin{tabular}{lll}
\hline Metal salts & $\begin{array}{l}\text { Tested concentration } \\
(\mathrm{mM})\end{array}$ & $\begin{array}{l}\text { Relative activity } \\
(\%)\end{array}$ \\
\hline Control & - & 100.0 \\
$\mathrm{~K}_{2} \mathrm{SO}_{4}$ & 5 & 91.4 \\
$\mathrm{CaCl}_{2}$ & 5 & 65.5 \\
$\mathrm{MgSO}_{4} \cdot 7 \mathrm{H}_{2} \mathrm{O}$ & 5 & 51.7 \\
$\left(\mathrm{NH}_{4}\right)_{2} \mathrm{SO}_{4}$ & 5 & 93.5 \\
$\mathrm{CoCl}_{2}$ & 1 & 40.2 \\
$\mathrm{ZnCl}_{2}$ & 1 & 35.4 \\
$\mathrm{KI}$ & 1 & 113.1 \\
$\mathrm{Na}_{2} \mathrm{MoO}_{4} \cdot 2 \mathrm{H} \mathrm{H}_{2} \mathrm{O}$ & 1 & 106.8 \\
$\mathrm{CuSO}_{4} \cdot 5 \mathrm{H}_{2} \mathrm{O}$ & 1 & 56.3 \\
$\mathrm{FeSO}_{4} \cdot 7 \mathrm{H}_{2} \mathrm{O}$ & 1 & 112.4 \\
$\mathrm{MnSO}_{4} \cdot 2 \mathrm{H}_{2} \mathrm{O}$ & 1 & 48.7 \\
\hline
\end{tabular}




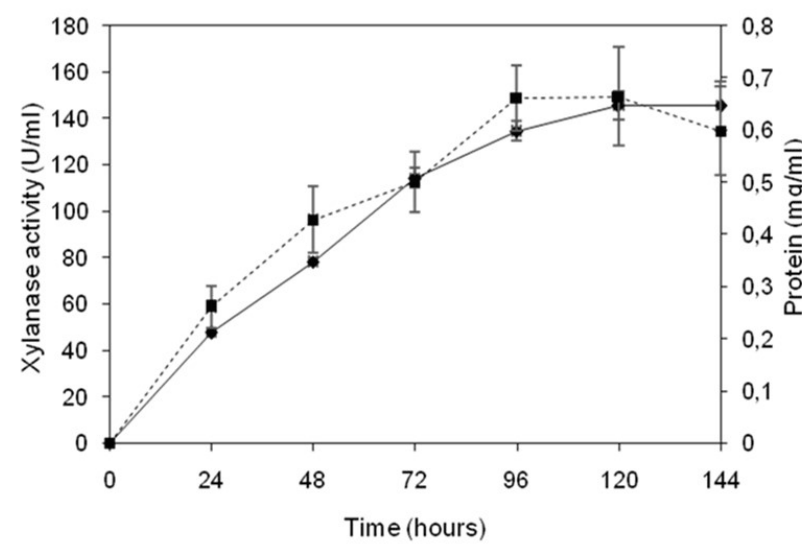

(a)

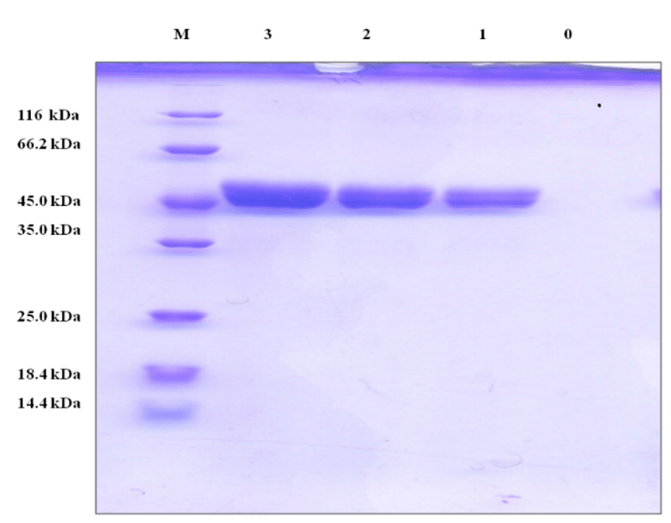

(b)

FIGURE 1 Expression of recombinant BHxyn3E in P. pastoris KM71. (a) Enzyme activity obtained by culturing the transformed $P$. pastoris in BMGY and induced with 3\% (v/v) methanol in BMMY. The culture supernatant was collected at day 1, 2, 3, 4, 5 and 6 and xylanase activity $(-\bullet-)$ and protein concentration (--) were measured; (b) SDS-PAGE analysis of the culture supernatant of the transformed P. pastoris expressing recombinant xylanase at 0, 24, 48 and $72 \mathrm{~h}$ (lanes 0-3). Lane $\mathrm{M}$ represents protein marker.

1a), furthermore, a four-day induction was chosen for the next experiment in order to reduce the process time and production cost. The transformant showed major bands with apparent molecular weights of approximately 46.7 $\mathrm{kDa}$ (Figure 1b), which was the size corresponded to the target xylanase from B. halodurans CM1. Qualitatively, the intensity of the bands also visualized the increment of protein expression from day 0 to 3 .

\subsection{Production of the recombinant xylanase by P. pas- toris in shake flask}

In this study, $P$. pastoris expressed optimum level of xylanase in BMGY medium deprived of zeocin $(135 \mathrm{U} / \mathrm{mL})$

TABLE 2 Effect of different enzyme dosages, anionic, and non-ionic surfactants on enhancing bagasse pulp hydrolysis.

\begin{tabular}{lll}
\hline Enzyme Dosage $(\mathrm{U} / \mathrm{g})$ & Reducing sugar $(\mathrm{mg} / \mathrm{g})$ & Xylose $(\mathrm{mg} / \mathrm{g})$ \\
\hline 0 & $1.1 \pm 0.88$ & $0.000 \pm 0.000$ \\
10 & $2.9 \pm 0.79$ & $\mathrm{ND}^{1}$ \\
20 & $3.29 \pm 0.95$ & $\mathrm{ND}^{1}$ \\
30 & $3.79 \pm 1.11$ & $\mathrm{ND}^{1}$ \\
40 & $5.4 \pm 0.98$ & $\mathrm{ND}^{1}$ \\
50 & $7.47 \pm 0.97$ & $0.476 \pm 0.002$ \\
75 & $9.43 \pm 1.33$ & $0.671 \pm 0.013$ \\
100 & $11.57 \pm 1.08$ & $0.870 \pm 0.023$ \\
200 & $23.84 \pm 1.36$ & $1.734 \pm 0.020$ \\
\hline Surfactant & Reducing sugar $(\mathrm{mg} / \mathrm{g})$ & Xylose $(\mathrm{mg} / \mathrm{g})$ \\
\hline Control & $10.5 \pm 0.63$ & 0.583 \\
Tween 20 & $15.53 \pm 0.64$ & 1.261 \\
Tween 80 & $18.10 \pm 0.65$ & 1.856 \\
Triton X-100 & $19.75 \pm 1.11$ & 2.712 \\
Lutensol & $17.92 \pm 0.59$ & 2.182 \\
Sanmorin & $4.59 \pm 0.69$ & 0.113 \\
\hline
\end{tabular}

${ }^{1}$ Not determined. after four days (Figure 1a). Comparatively, the enzyme productivity was slightly lower in yeast cell cultured in BMGY medium with zeocin (129 U/mL) after four days of induction (Figure 2a). The growth of $P$. pastoris in both treatments were in the same range throughout the process, yet enzyme production was consistently observed higher in the cultures with no zeocin from day 1 to 4 , although not significant (Figure 2a). The zeocin has no role in plasmid maintenance and only function to minimalize contamination, which was not the main issue in upscale production. It is a good agreement with the report of Chantasingh et al. (2006), Mohd Dali et al. (2011), Lin et al. (2013), and Shang et al. (2017). One of our targets was to establish protein production in the minimum cost. Thus, further experiments on cultivation of $P$. pastoris were performed using the medium lacking zeocin since no supplementation of it could reduce the cultivation cost.

To optimize the production of the recombinant $x y-$ lanase, the effect of various methanol concentrations towards enzyme expression was investigated in a volume of $100 \mathrm{~mL}$ BMGY culture. Four different methanol concentrations (1, 2, 3 and $4 \% \mathrm{v} / \mathrm{v})$ were added to the culture medium at the induction phase. After four days of induction, the secreted xylanase from culture medium induced with both $2 \%$ and $3 \%(\mathrm{v} / \mathrm{v})$ methanol was higher in activities, of around $135 \mathrm{U} / \mathrm{mL}$, than other concentrations (Figure $2 \mathrm{~b}$ ). However, the greatest yield of specific activity of $358 \mathrm{U} / \mathrm{mg}$ was obtained from the culture supernatant induced by $2 \%(\mathrm{v} / \mathrm{v})$ methanol, thus with cost-efficiency for upscale consideration, methanol at $2 \%(\mathrm{v} / \mathrm{v})$ was chosen for further experiment.

\subsection{Enzyme characterization}

\subsubsection{Effect of $\mathrm{pH}$ and temperature on xylanase ac- tivity and stability}

The enzyme activity of recombinant $B$. halodurans CM1 xylanase was determined in the $\mathrm{pH}$ range of 5-10 in the 


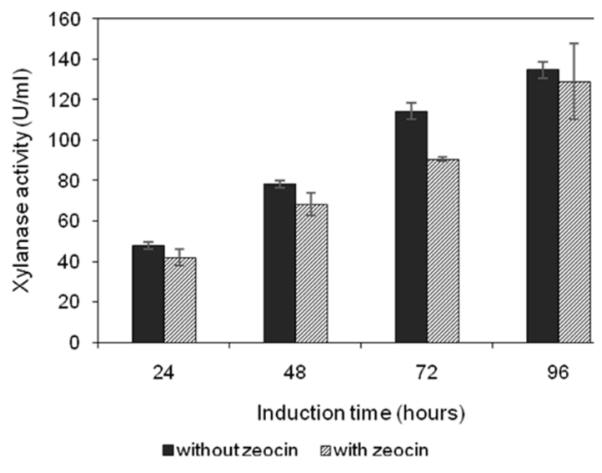

(a)

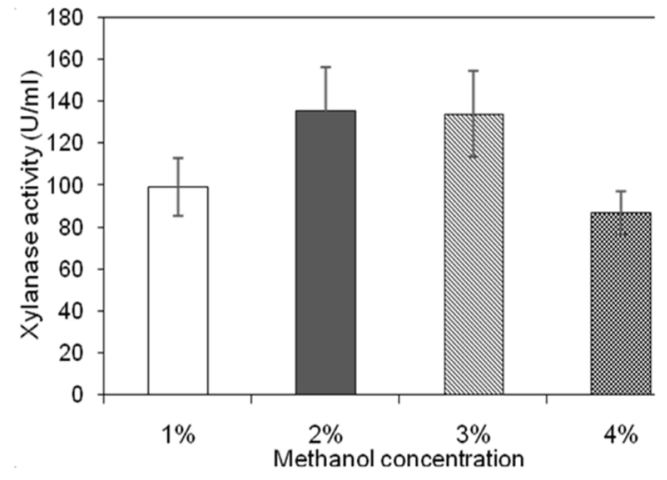

(b)

FIGURE 2 Effect of the presence of zeocin and methanol concentration on expression level of recombinant BHxyn3E. (a) Comparison of enzyme activity in the presence of zeocin and without zeocin; (b) Production of the recombinant xylanase was analyzed by culturing the transformed P. pastoris in BMGY and induced with various methanol concentrations (1, 2, 3 and $4 \% \mathrm{v} / \mathrm{v})$ in BMMY. The culture supernatant was collected at day 4 and determined the xylanase activity by DNS method.

buffers with similar ionic concentrations. As the results in Figure 3, the maximum activity was found at $\mathrm{pH} 8$ and its activity was stable over a board $\mathrm{pH}$ range of $6-10$. Furthermore, this enzyme retained more than $80 \%$ of its optimal activity at higher $\mathrm{pH}(9-10)$ with the maximum activity at pH 8 (Figure 3a). The pH stability was investigated by pre-incubating the enzyme in various buffers with the $\mathrm{pH}$ range of $6-10$ at $60{ }^{\circ} \mathrm{C}$ for $1 \mathrm{~h}$ and the remaining activity was monitored at $\mathrm{pH}$ 8.0. The activity of enzyme was stable between $\mathrm{pH} 7-10$, remaining over $75 \%$ of its maximal activity (Figure 3b). The effect of temperature on xylanase activity was accessed in the range of $30-80{ }^{\circ} \mathrm{C}$ in $50 \mathrm{mM}$ Tris-HCl buffer (pH 9.0) and the recombinant enzyme displayed the highest activity at $60{ }^{\circ} \mathrm{C}$. Over $50 \%$ of its maximal activity was found at $45-65{ }^{\circ} \mathrm{C}$ (Figure 3c). To investigate thermostability of the recombinant xylanase, the enzyme was incubated in the range of $50-70{ }^{\circ} \mathrm{C}$ for various periods of time in the same buffer as described in the materials and methods section. As shown in Figure 3d, the enzyme was stable at only $50{ }^{\circ} \mathrm{C}$ with more than $50 \%$ of its maximal activity was retained. At higher temperature (60 and $70{ }^{\circ} \mathrm{C}$ ), the enzyme rapidly become inactive after incubating for $15 \mathrm{~min}$ (Figure 3d).

\subsubsection{Effect of metal ions and salts on xylanase activ- ity}

The effect of various metal ions on the enzyme activity was investigated. As indicated in Table 1, the residual activity of the enzyme was slightly increased by ion $\mathrm{K}^{+}$ (113.10\%), $\mathrm{Fe}^{2+}(112.40 \%)$ and $\mathrm{MoO}_{4}{ }^{2-}(106.80 \%)$, while significant decrement by $\mathrm{Zn}^{2+}$ (35.40\%), $\mathrm{Co}^{2+}$ (40.20\%), $\mathrm{Mn}^{2+}$ (48.70\%), $\mathrm{Mg}^{2+}$ (51.70\%), $\mathrm{Cu}^{2+}$ (56.30\%) and $\mathrm{Ca}^{2+}$ (65.50\%) was observed (Table 1). The salts, K2SO4 and $\left(\mathrm{NH}_{4}\right)_{2} \mathrm{SO}_{4}$ had weak effects on inhibiting the enzymatic activity (91.40 and 93.50\%, respectively; Table 1).

\subsection{Application of recombinant xylanase from B. halo- durans CM1 in bagasse pulp bleaching}

The potential of using the recombinant xylanase as a pulp bleach booster was preliminarily monitored by analyzing the hydrolysis efficacy of the enzyme on industrial bagasse pulp. The potential of pulp hydrolysis enzyme was pre-evaluated using various enzyme dosages with 10 g moisture-free pulp at $10 \%(\mathrm{w} / \mathrm{v})$ consistency. Hence, the amount of reducing sugar liberated from the pulp was analyzed. As shown in Table 2, increase of reducing sugars was observed with higher enzyme dosages. A maximum reducing sugar of $23.84 \mathrm{mg} / \mathrm{g}$ was obtained at $200 \mathrm{U} / \mathrm{g}$ before stationary condition (Table 2). Furthermore, xylose and glucose quantification of the solutions obtained from the enzyme-treated pulp reactions was carried out using HPLC with Aminex ${ }^{\circledR}$ column. As shown in Table 2, the xylose content revealed a similar trend with the previous reducing sugar analysis, depicting the xylose amount of $1.73 \mathrm{mg} / \mathrm{g}$ at $200 \mathrm{U} / \mathrm{g}$ (Table 2) was the most reasonable amount, whereas no detectable amounts of glucose were observed from all samples tested in HPLC analysis (data not shown). Hence, the recombinant xylanase at $200 \mathrm{U} / \mathrm{g}$ was then chosen for further studies. This result suggested that the recombinant xylanase is cellulase-free xylanase.

To enhance the potential characterization of enzyme, various non-ionic and anionic surfactants were supplemented in the enzyme-pulp reactions at the concentration of $0.25 \%(\mathrm{w} / \mathrm{v})$ and the reducing sugar and xylose contents released from the pulp were quantified. As indicated in Table 3, all non-ionic surfactants evaluated (Tween 20, Tween 80, Triton X-100 and Lutensol) had an activated effect on the recombinant enzyme and maximum release of reducing sugars (19.75 mg/g; 1.88 folds higher than control). The xylose content $(2.71 \mathrm{mg} / \mathrm{g} ; 4.65$ folds higher than control) was observed in the enzyme-treated solution supplemented with Triton X-100. The pulp with Triton 


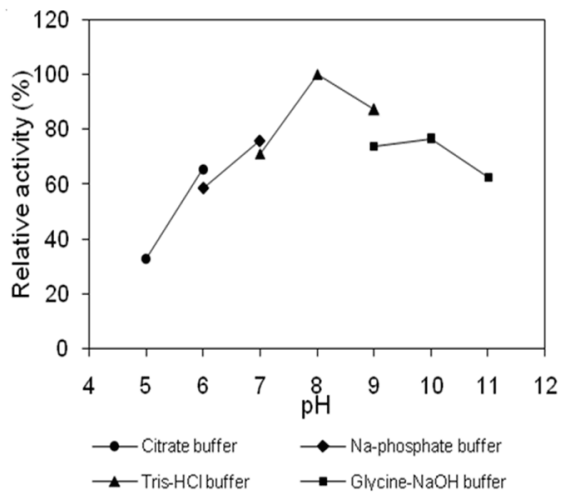

(a)

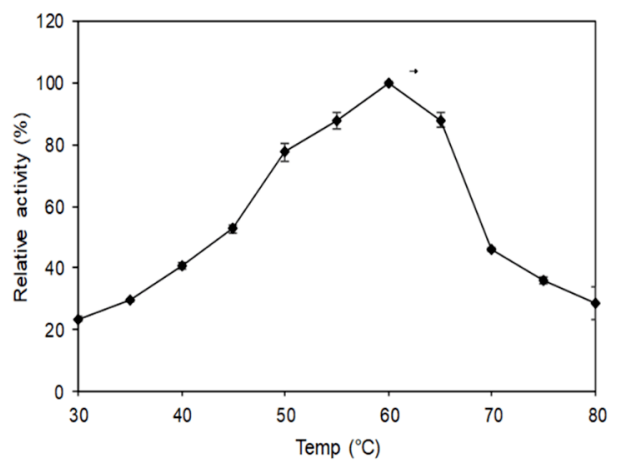

(c)

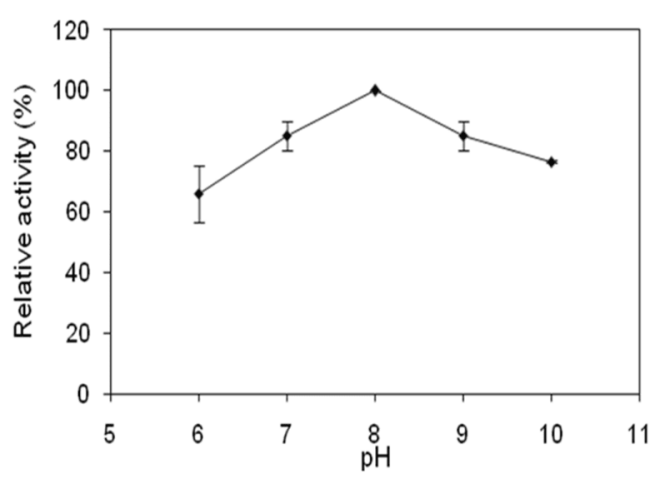

(b)

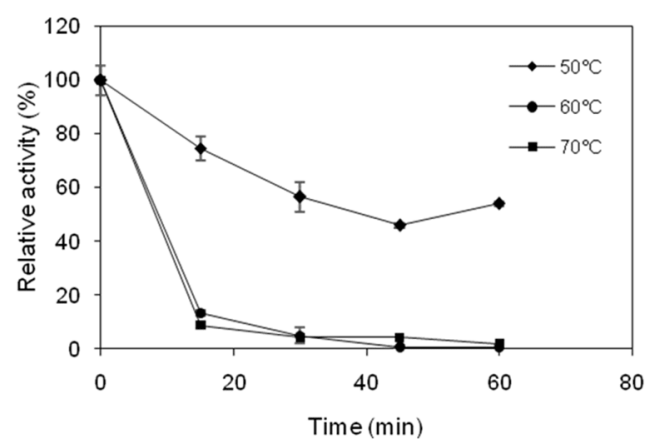

(d)

FIGURE 3 Effects of $\mathrm{pH}$ and temperature on the activity and stability, and Lineweaver-Burk plotting graph of recombinant BHxyn3E produced by P. pastoris. (a) Optimal pH: The reactions consisted of $1 \%(\mathrm{w} / \mathrm{v})$ of beechwood xylan in $50 \mathrm{mM}$ sodium citrate ( $\mathrm{pH} 5.0)$, sodium phosphate (pH 6.0 to 8.0), Tris- $\mathrm{HCl}\left(\mathrm{pH} 8.0\right.$ to 9.0), or Glycine- $\mathrm{NaOH}$ ( $\mathrm{pH} 9.0$ to 10.0) buffer were prepared and incubated at $60^{\circ} \mathrm{C}$ for $5 \mathrm{~min}$; (b) pH stability: The enzyme was pre-incubated in $50 \mathrm{mM}$ buffers at $60^{\circ} \mathrm{C}$ for 1 hour and residual activity was measured under the standard assay conditions. The buffers used were sodium phosphate (pH 6.0 to 8.0), Tris- $\mathrm{HCl}$ (pH 8.0 to 9.0), and glycine- $\mathrm{NaOH}$ (pH 9.0 to 10.0); (c) Optimal temperature: the reactions were assayed over a temperature range of 30 to $80^{\circ} \mathrm{C}$ at optimal pH for $5 \mathrm{~min}$; (d) Thermostability: The xylanase was pre-incubated over various temperatures $\left(50,60\right.$ and $\left.70^{\circ} \mathrm{C}\right)$ at optimal $\mathrm{pH}$ for different times $(15,30,45$ and 60 min) prior to residual activity analysis under the assayed conditions.

$\mathrm{X}-100$ only was used as a control to confirm the Triton $\mathrm{X}-100$ alone did not affect the xylan degradation. It was found that anionic surfactant (Sanmorin) acted as an inhibitor in reducing the amounts of reducing sugars (4.59 $\mathrm{mg} / \mathrm{g} ; 2.88$ folds lower than control) and xylose (0.113 $\mathrm{mg} / \mathrm{g} ; 5.16$ folds lower than control) (Table 2). This result suggested that the non-ionic surfactants, particularly Triton X-100 plays essential role in enhancing the xylanase

TABLE 3 Effect of B. halodurans CM1 xylanase on the Lab color space of pulps.

\begin{tabular}{lllll}
\hline \multirow{2}{*}{ Treatment } & \multicolumn{3}{l}{ Color opponent ${ }^{1}$} & \\
\cline { 2 - 5 } & $\mathrm{L}^{*}$ & $\mathrm{a}^{*}$ & $\mathrm{~b}^{*}$ & \\
\hline Unbleached pulp & $81.59 \pm 0.44$ & $1.97 \pm 0.03$ & $11.56 \pm 0.18$ & $78.17 \pm 0.47$ \\
$\mathrm{H}_{2} \mathrm{O}$ (untreated control) & $87.40 \pm 0.33$ & $0.88 \pm 0.02$ & $11.84 \pm 0.72$ & $82.69 \pm 0.73$ \\
Xylanase & $87.51 \pm 0.08$ & $0.97 \pm 0.03$ & $11.36 \pm 0.23$ & $83.09 \pm 0.21$ \\
Xylanase+Triton X-100 & $88.70 \pm 0.23$ & $1.00 \pm 0.01$ & $11.49 \pm 0.46$ & $83.85 \pm 0.48$ \\
\hline
\end{tabular}

${ }_{1} \mathrm{~L}^{*}$ represents lightness; $\mathrm{a}^{*}$ represents color opponent from green (-ve) tomagenta (+ve); and $\mathrm{b}^{*}$ indicates color opponent from blue (-ve) to yellow (+ve) based on nonlinearly compressed CIE XYZ color space coordinates.

${ }^{2} \mathrm{WI}$ represents whiteness index that was obtained by measuring $\mathrm{L}^{*} \mathrm{a}^{*} \mathrm{~b}$ values of thepulp samples and the CIE WI was then calculated based on the equation: $\mathrm{WI}=100-\left[(100-\mathrm{L})^{2}+\mathrm{a}^{2}+\mathrm{b}^{2}\right]^{0.5}$. 
activity, leading to higher degradation enzymatic activity in pulp biobleaching.

Among the pulp hydrolysis experiments carried out at various contents of Triton X-100, the highest liberation of the reducing sugars was observed from the solution of the enzymatic treated pulp added with $0.25 \%(\mathrm{w} / \mathrm{v})$ of Triton X-100 (data not shown). Therefore, biobleaching of bagasse pulp was then carried out using the xylanase and Triton X-100 at the concentrations of $200 \mathrm{U} / \mathrm{g}$ and $0.25 \%$ $(\mathrm{w} / \mathrm{v})$, respectively. Surfactants alone have no role in pulp hydrolysis, as we have observed a control with only Triton $\mathrm{X}-100$ in the reaction produced no reducing sugars (data not shown).

The bleaching efficiency of the enzyme on the bagasse pulp was evaluated based on its effects on pulp whiteness index (WI) using the 3-step bleaching sequence [(X)HEp]. Without including the standard deviation, pretreatment of the bagasse pulps with the recombinant xylanase exhibited an enhancement of pulp whiteness. The highest WI (83.85\% CIE) although not significant was achieved from the pulp treated with Triton X100-mixed enzyme, followed by pulp treated with xylanase alone (83.09\% CIE) (Table 3). In addition, the component of the whiteness index, namely Lightness index $\left(\mathrm{L}^{*}\right)$ and Color a index $\left(\mathrm{a}^{*}\right)$ changed by the Triton X100-mixed enzyme treatment over the untreated control (Table 3).

\subsection{Discussion}

This study described the characterization of recombinant xylanase from $B$. halodurans CM1 produced by $P$. pastoris KM71 and the potential application of the enzyme in biobleaching of bagasse pulp. The cloning and expression of xylanase gene originating from Japanese B. halodurans C-125 have been reported, however, the xylanase produced was applied in the wheat straw pulp (Lin et al. 2013). This study is the first report of recombinant $x y-$ lanase bagasse pulp application from Indonesian B. halodurans expressed in $P$. pastoris. The cloning of an endoxylanase encoding gene from $B$. halodurans CM1 strain using pET21d vector in E. coli BL21 star has been previously conducted. Based on these results, the obtained recombinant enzymes showed a promising in deinking process of waste paper (Helianti et al. 2018). However, the level of secreted enzyme from recombinant $E$. coli was very low, around $10 \mathrm{U} / \mathrm{mL}$ (19.73 U/mg) and only after purification with Ni-NTA it reached $543 \mathrm{U} / \mathrm{mg}$. Therefore, in this study, we tried to increase the enzyme productivity by substitution of expression system in P. pastoris as a host cell.

The volumetric activity of extracellular xylanase by $P$. pastoris was more than 10 -folds higher compared to recombinant xylanase expressed in E. coli (Helianti et al. 2018) without downstream purification, thus showing that this $P$. pastoris is promising to be recombinant host in upscale production since it gave a better yield of enzyme productivity. In terms of purified enzyme, the recombinant xylanase produced by P. pastoris also offers a more straightforward purification system compared to E. coli expression system. Therefore, the step of purification process was shorter and no need to do a further succesive purification system, which can reduce the cost for the downstream process.

The recombinant xylanase produced by $P$. pastoris had optimum activity at $\mathrm{pH} 8$ and temperature $60^{\circ} \mathrm{C}$. This result was slightly different with the optimal $\mathrm{pH}$ and temperature of recombinant xylanase expressed in E. coli $(\mathrm{pH} 9$ and $65^{\circ} \mathrm{C}$ ) or native enzyme in wild-type bacterium $(\mathrm{pH}$ 9 and $70^{\circ} \mathrm{C}$ ). (Ulfah et al. 2011; Helianti et al. 2018). The difference in biochemical properties also found in the other enzymes, such as lipase and cellulase (Zhu et al. 2014; de Amorim Araújo et al. 2015; Tišma et al. 2019), that expressed in different host cell system. This result might be occurred due to the post-translational protein modification in P. pastoris (Guerrero-Olazarán et al. 2010; Gomes et al. 2016; Chae et al. 2017; Vieira Gomes et al. 2018).

The other properties such as the effect of metal ions on this xylanase have not been studied previously, and this xylanase unexpectedly inactivated by $\mathrm{Ca}^{2+}$, which is similar to Bacillus subtilis xylanase was reported by Sanghi et al. (2010) and different to Bacillus amyloliquefaciens xylanase reported by Kumar et al. (2017). Thus, different xylanase has their unique preference for metal ions. This information is useful in the application aspect, so that we have to omit the decreasing effect of metal ion both in fermentation or in the application.

In order to enhance the efficient use of the recombinant xylanase, various surfactants have been examined for their ability in promoting the increment of xylanase activity on bagasse pulp hydrolysis. In this study, the addition of non-ionic surfactant such as Triton X-100 to the hydrolysis reaction allowed an increase in reducing sugars and xylose content of 1.88 and 4.65 folds higher than control, respectively. Corresponding to other reports, Triton $\mathrm{X}-100$, Tween 80 , and Tween 20 were widely used and proven to increase hydrolysis of sugarcane bagasse and other types of raw straws by acting along in promoting various kind of lignocellulose-degrading enzymes such as xylanase, cellulase, and endoglucanase (Wang et al. 2011; Cheng et al. 2014). The bagasse pulp pretreated with crude recombinant xylanase and Triton X-100 exhibited 1.40\% CIE increase in the whiteness compared to the untreated control pulp, while only $0.40 \%$ CIE increase in whiteness was observed in the pulp treated with enzyme alone. However, Xylanase+Triton X100 treatment increased the lightness index $\left(\mathrm{L}^{*}\right)$ and changed substantially the color a index $\left(a^{*}\right)$.

The increment of the whiteness index (WI) of the xylanase-prebleached pulp hand sheets in this study was somehow not significant. This could be due to the enzyme was not stable as the retaining activity was dropped below $20 \%$ in the first $15 \mathrm{~min}$ at bleaching temperature $\left(60^{\circ} \mathrm{C}\right)$, although it could maintain its stability at more than $50 \%$ after an hour incubation at $50^{\circ} \mathrm{C}$. Another factor to be put into consideration was the bleaching process occurred in no $\mathrm{pH}$ adjustment using pulp with $\mathrm{pH} 9.0$, since the best $\mathrm{pH}$ stability of this recombinant xylanase was $\mathrm{pH}$ 8.0. There- 
fore, the operation condition was not optimal for the enzyme to work steadily throughout the process. Although in many studies pre-bleaching experiments with enzymes were still primarily done at its optimum temperature (Nair et al. 2010; Weerachavangkul et al. 2012; Lin et al. 2013), the stability of the enzyme after a period of incubation at optimal temperature should also be observed.

Based on Vena et al. (2013), the sugarcane bagasse usually contained $25.9 \% \pm 2.1$ xylan. However, how much xylan present in pulp are diversely varied based on how the pulping was carried out, and from this paper as an example, the mild alkaline pulp could have $6.2 \%$ xylan of the pulp. If we assumed this may be closed to the pulp we used in our experiment, it means, if we used $10 \mathrm{~g}$ of dried pulp, theoretically, there is $620 \mathrm{mg}$ xylan in it. Therefore, if we use $200 \mathrm{U} / \mathrm{g}$ enzyme dosage, based on Table 2, theoretically $238.4 \mathrm{mg}$ of xylan could be degraded and the effect could be seen, if it is in optimal and enzyme stable condition.

Optimal enzyme charge of $200 \mathrm{OD} / \mathrm{g}$ in this study was considered as high compared to another study of bleaching with $B$. halodurans xylanase with wheat straw pulp (Lin et al. 2013), however, the optimal dosage of enzyme varied considerably depending on the type of pulp and microbial xylanase characteristics used in the experiment. Apart from reporting optimal enzyme charge and Triton X-100 positive effect in bagasse pulp bleaching, our results from this study has given the rise of concerns regarding the importance of the optimization of bleaching conditions that is suitable for enzyme to operate for the next assessment.

\section{Conclusions}

In conclusion, characterization of alkaliphilic and thermophilic xylanase originated from a new Indonesian strain (CM1) of B. halodurans produced by $P$. pastoris and its potential application in bleaching bagasse pulp has been reported in this work. The full characterization of the recombinant xylanase and its application in bleaching bagasse pulp is the new information. The ability of the enzyme for biobleaching of bagasse pulp has been confirmed in the first screening for further application, where it slightly increased the pulp whiteness with no necessary for $\mathrm{pH}$ adjustment of an incoming pulp. However, further optimization and assessment in biobleaching were needed for industrial application, the usage of this enzyme could be an alternative solution for environmentally friendly pulp bleaching process in the industry.

\section{Acknowledgments}

The main of this research study is under the collaborative program between Center of Bioindustrial Technology, Agency of Assessment and Application of Technology (BPPT) and National Center for Genetic Engineering and Biotechnology (BIOTEC), National Science and Technology Development Agency (NSTDA). Unbleached bagasse pulp for pulp bleaching experiment was obtained from Environment Pulp and Paper Co. Ltd., a local pulp and paper manufacture in Thailand, as a kind gift. Additional experiments were done in Indonesia were funded by Incentive National Innovation System (INSINAS) Research Grant 2019-2020 from Indonesia Ministry of Research and Technology granted to IH.

\section{Authors' contributions}

H, LM, IH are main contributors. PP, KK, DC, and TN are also main contributors. IH supervised and designed the overall study, KK supervised and designed the study of fermentation, DC supervised the genetic engineering work in Pichia, TN supervised and designed the study of bleaching application. H, LM carried out the laboratory work and analyzed the data with technical assistance of PP as lab mentor. $\mathrm{H}$ wrote the original manuscript, and IH, PP, TN reviewed and edited it, and IH edited and approved the final revision. All authors have read and approved the final version of the manuscript.

\section{Competing interests}

The author declare that they have no competing interest.

\section{References}

Bailey MJ, Biely P, Poutanen K. 1992. Interlaboratory testing of methods for assay of xylanase activity. J Biotechnol. 23(3):257-270. doi:10.1016/01681656(92)90074-J.

Bhardwaj N, Kumar B, Verma P. 2019. A detailed overview of xylanases: an emerging biomolecule for current and future prospective. Bioresour Bioprocess. 6(1). doi:10.1186/s40643-019-0276-2.

Chae YK, Kim SH, Markley JL. 2017. Relationship between recombinant protein expression and host metabolome as determined by twodimensional NMR spectroscopy. PLoS ONE. 12(5). doi:10.1371/journal.pone.0177233.

Chantasingh D, Pootanakit K, Champreda V, Kanokratana P, Eurwilaichitr L. 2006. Cloning, expression, and characterization of a xylanase 10 from Aspergillus terreus (BCC129) in Pichia pastoris. Protein Expression Purif. 46(1):143-149. doi:10.1016/j.pep.2005.09.013.

Cheng J, Yu Y, Zhu M. 2014. Enhanced biodegradation of sugarcane bagasse by Clostridium thermocellum with surfactant addition. Green Chem. 16(5):2689-2695. doi:10.1039/c3gc42494d.

de Amorim Araújo J, Ferreira TC, Rubini MR, Duran AGG, De Marco JL, de Moraes LMP, Torres FAG. 2015. Coexpression of cellulases in Pichia pastoris as a self-processing protein fusion. AMB Express. 5(1):1-10. doi:10.1186/s13568-015-0170-z. 
Gomes A, Byregowda S, Veeregowda B, Balamurugan V. 2016. An overview of heterologous expression host systems for the production of recombinant proteins. Adv Anim Vet Sci. 4(4):346-356. doi:10.14737/journal.aavs/2016/4.7.346.356.

Guerrero-Olazarán M, Rodríguez-Blanco L, CarreonTreviño JG, Gallegos-López JA, Viader-Salvadó JM. 2010. Expression of a bacillus phytase $\mathrm{C}$ gene in Pichia pastoris and properties of the recombinant enzyme. Appl Environ Microbiol. 76(16):5601-5608. doi:10.1128/AEM.00762-10.

Helianti I, Ulfah M, Noer S, Nurhayati N, Saefudin E. 2018. Cloning and expression of alkalophilic xylanase gene from an Indonesia local Bacillus halodurans CM1 in Escherichia coli and its application on deinking process of waste paper. Malays J Microbiol. 14(7):655-662. doi:10.21161/mjm.114217.

Hidayat H, Yasuyuki K. 2012. Emerging Pulp and Paper Industry in Thailand. Jurnal Kajian Wilayah. 3(1):117-137. doi:10.14203/jkw.v3i1.315.

Jeya M, Thiagarajan S, Lee JK, Gunasekaran P. 2009. Cloning and expression of GH11 xylanase gene from Aspergillus fumigatus MKU1 in Pichia pastoris. J Biosci Bioeng. 108(1):24-29. doi:10.1016/j.jbiosc.2009.02.003.

Kumar S, Haq I, Prakash J, Singh SK, Mishra S, Raj A. 2017. Purification, characterization and thermostability improvement of xylanase from Bacillus amyloliquefaciens and its application in pre-bleaching of kraft pulp. 3 Biotech. 7(1). doi:10.1007/s13205-017-0615$\mathrm{y}$.

Lin XQ, Han SY, Zhang N, Hu H, Zheng SP, Ye YR, Lin Y. 2013. Bleach boosting effect of xylanase A from Bacillus halodurans C-125 in ECF bleaching of wheat straw pulp. Enzyme Microb Technol. 52(2):91-98. doi:10.1016/j.enzmictec.2012.10.011.

Miller GL. 1959. Use of Dinitrosalicylic Acid Reagent for Determination of Reducing Sugar. Anal Chem. 31(3):426-428. doi:10.1021/ac60147a030.

Mohd Dali NS, Nuge T, Mahamad Maifiah MH, Yusof F, Meor Hussin AS, Farouk AE, Mohd Salleh, Hamzah. 2011. Molecular Cloning and Production of Recombinant Phytase from Bacillus subtilis ASUIA243 in Pichia pastoris. IIUM Eng J. 12(4):99108. doi:10.31436/iiumej.v12i4.211.

Nair SG, Sindhu R, Shashidhar S. 2010. Enzymatic bleaching of kraft pulp by xylanase from Aspergillus sydowii SBS 45. Indian J Microbiol. 50(3):332-338. doi:10.1007/s12088-010-0049-2.

Nimchua T, Thongaram T, Uengwetwanit T, Pongpattanakitshote S, Eurwilaichitr L. 2012. Metagenomic analysis of novel lignocellulose-degrading enzymes from higher termite guts inhabiting microbes. J Microbiol Biotechnol. 22(4):462-469. doi:10.4014/jmb.1108.08037.

Sanghi A, Garg N, Gupta VK, Mittal A, Kuhad RC. 2010. One-step purification and characterization of cellulase-free xylanase produced by alkalophilic
Bacillus subtilis ASH. Braz J Microbiol. 41(2):467476. doi:10.1590/S1517-83822010000200029.

Shang T, Si D, Zhang D, Liu X, Zhao L, Hu C, Fu Y, Zhang R. 2017. Enhancement of thermoalkaliphilic xylanase production by Pichia pastoris through novel fed-batch strategy in high cell-density fermentation. BMC Biotechnol. 17(1). doi:10.1186/s12896-0170361-6.

Sudaryanto AY, Wibowo SH, Purnomo YY. 2008. The effect of chemical and biopulping process on bagasse pulp. Dev Chem Eng Miner Process. 13(5-6):639644. doi:10.1002/apj.5500130513.

Tišma M, Tadić T, Budžaki S, Ostojčić M, Šalić A, Zelić B, Tran NN, Ngothai Y, Hessel V. 2019. Lipase Production by Solid-State Cultivation of Thermomyces Lanuginosus on By-Products from ColdPressing Oil Production. Processes. 7(7):465. doi:10.3390/pr7070465.

Ulfah M, Helianti I, Wahyuntari B, Nurhayati N. 2011. Characterization of a New Thermoalkalophilic Xylanase-Producing Bacterial Strain Isolated from Cimanggu Hot Spring,West Java, Indonesia. Microbiol Indones. 5(2):139-143. doi:10.5454/mi.5.3.7.

Vena PF, García-Aparicio MP, Brienzo M, Görgens JF, Rypstra T. 2013. Impact of hemicelluloses preextraction on pulp properties of sugarcane bagasse. Cellulose Chem Technol. 47(5-6):469-477.

Vieira Gomes A, Souza Carmo T, Silva Carvalho L, Mendonça Bahia F, Parachin N. 2018. Comparison of Yeasts as Hosts for Recombinant Protein Production. Microorganisms 6(2):38. doi:10.3390/microorganisms6020038.

Walia A, Guleria S, Mehta P, Chauhan A, Parkash J. 2017. Microbial xylanases and their industrial application in pulp and paper biobleaching: a review. 3 Biotech. 7(1). doi:10.1007/s13205-016-0584-6.

Wang HY, Fan BQ, Li CH, Liu S, Li M. 2011. Effects of rhamnolipid on the cellulase and xylanase in hydrolysis of wheat straw. Bioresour Technol. 102(11):65156521. doi:10.1016/j.biortech.2011.02.102.

Weerachavangkul C, Laothanachareon T, Boonyapakron K, Wongwilaiwalin S, Nimchua T, Eurwilaichitr L, Pootanakit K, Igarashi Y, Champreda V. 2012. Alkaliphilic endoxylanase from lignocellulolytic microbial consortium metagenome for biobleaching of eucalyptus pulp. J Microbiol Biotechnol. 22(12):16361643. doi:10.4014/jmb.1206.06044.

Zhao L, Geng J, Guo Y, Liao X, Liu X, Wu R, Zheng Z, Zhang R. 2015. Expression of the Thermobifida fusca xylanase Xyn11A in Pichia pastoris and its characterization. BMC Biotechnol. 15(1). doi:10.1186/s12896-015-0135-y.

Zhu J, Liu H, Zhang J, Wang P, Liu S, Liu G, Wu L. 2014. Effects of Asn-33 glycosylation on the thermostability of Thermomyces lanuginosus lipase. J Appl Microbiol. 117(1):151-159. doi:10.1111/jam.12519. 